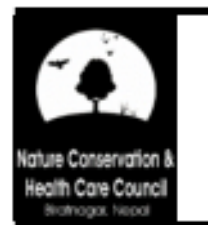

Our Nature

\title{
Branchial muscles of a Hill-stream Cyprinid fish Neolissochilus hexagonolepis (McClelland,1839)
}

\author{
Jawan Tumbahangfe ${ }^{1^{*}}$, Bharat Raj Subba ${ }^{2 * *}$ and Archana Prasad ${ }^{3 * * *}$ \\ I"Punya Higher Secondary School, Rajarani, Dhankuta, Nepal \\ ${ }^{*}$ Department of Zoology, Post Graduate Campus, Tribhuvan.University, Biratnagar, Nepal \\ ${ }^{3}$ Central Department of Zoology, Tribhuvan University, Kirtipur, Kathmandu, Nepal \\ *E-mail: jawan_subba@yahoo.com \\ ${ }^{* *}$ E-mail: subbabharatraj@gmail.com \\ ***E-mail: aprasad@cdztu.edu.np
}

\begin{abstract}
Different branchial muscles associated with the gill arches and gill filaments in a hill-stream cyprinid fish Neolissochilus hexagonolepis have been studied. The main branchial muscles observed are the constrictors branchiales, levatores arcuum branchialium epiarcualia obliqui, epiarcualia recti, subarcualia obliqui, subarcualia recti and subarcualia transversi. In the general plan the branchial muscles of $N$. hexagonolepis show similarity with those of other cyprinid fishes. However, the fish bears three pairs of coracobranchiales, common to cyprinid fishes.
\end{abstract}

Key words: Coracobranchiales, Branchial movement, Gill raker, hemibranch

\footnotetext{
DOI: http://dx.doi.org/10.3126/on.v16i1.22125

Manuscript details: Received: 19.06 .2018 / Accepted: 12.10 .2018

Citation: Tumbahangfe, J., B.R. Subba and A. Prasad 2018 Branchial muscles of a Hill-stream Cyprinid fish Neolissochilus hexagonolepis (McClelland,1839), Our Nature 16(1): 74-79. DOI: http://dx.doi.org/ 10.3126/on.v16i1.22125

Copyright: $\odot$ Tumbahangfe, Subba and Prasad 2018. Creative Common Attribution - Non Commercial 4.0 International License.
}

\section{Introduction}

In fish, branchial arches and the gill filaments are brought in movement by a series of branchial muscles. The respiratory movements in fish are closely associated with the dilation and subsequent contraction of the bucco-pharynx. The branchial muscles in fishes have been studied and described by several workers. Among the earlier workers, special references may be made of Duvernoy (1839), Reiss (1981), Rauther (1925), Edgeworth (1935) and Kesteven (1942-43). Bijtel (1947, 1949), Subba and Ghosh (1999), Shrestha and Subba (2006) worked on a number of fishes and concluded that the adductor muscles of the gills were responsible for the coughing movements in fishes.

In the present study, the branchial muscles of a hill-steam cyprinid fish, Neolissochilus hexagonolepis have been studied in relation to branchial movements.

\section{Materials and methods}

A few adult specimens were collected from Tamor river at Dumrebesi (N 26056'19.0", E $\left.087^{0} 22^{\prime} 18.9^{\prime \prime}\right)$ Dhankuta, Nepal, with the help of local fishermen and fixed in ethanol then brought to zoology laboratory of Post Graduate Campus, Biratnagar. The specimens were dissected carefully to expose the branchial muscles of the different gill arches. The branchial muscles dissected out from fresh specimens were fixed in $70 \%$ ethanol for further studies. Small pieces of gills of freshly killed fish were fixed in Bouin's and Zenker's fixatives for the study of histology of the muscles of gill filament.

The large specimens fixed in ethanol were dissected out without using microscope but the binocular microscope was used to confirm attachment of some of the branchial muscles. Small pieces of gills were decalcified and paraffin blocks were prepared then 5-6 $\mu \mathrm{m}$ thick 
sections were cut and stained with haematoxylin/eosin. A few Alizarin preparations were also made. $1 \mathrm{~g}$ Alizarin was dissolved in1lit.of $1 \%$ of $\mathrm{KOH}$ solution. A suitable sized fish already fixed in formalin for $12 \mathrm{hrs}$ was washed in running water for 24-48hrs after that transferred to $1 \% \mathrm{KOH}$ solution and left for 48 hrs. or so till the material became transparent. The transparent fish was transferred to Alizarin solution and kept till the bones were stained red then stored in pure glycerin for observation.

\section{Results and discussion}

The Alizarine preparations were especially helpful in understanding the relationship between the muscles and skeleton of the branchial arches. In Neolissochilus hexagonolepis, the following branchial muscles were observed (Fig.1 and Tab.1).

a) The Constrictores branchiales (Constrictor branchialis): In $N$. hexagonolepis, the constrictor branchiales consists of two parts (i) Abductor and (ii) adductor muscle units.

(i) The abductor muscle unit: A sheet of muscle situated on the outer side of the holobranch represents the abductor muscle unit. This sheet gradually tapers from the epibranchial region to ceratobranchial to hypobranchial region (Fig.1. a, b, c,) of the gill arch. Fibrous connective tissue connects the gill rays' heads with the gill arch.

(ii) The adductor muscle unit: The adductor muscles lie in the inter branchial septum which is reduced and covers only about $22 \%$ of the total length of the primary filament. The muscle fibre take their origin from the opposite gill rays. Their tendons cross each other and become inserted on to the gill rays of the opposite hemibranch.

The two muscle components of constrictors branchiales, namely, the abductor and adductor muscles show close conformity in their structure and disposition with those of other Siluroid fishes viz. Clarias batrachus (Munshi, 1961) and Heterpneustes fossilis (Munshi, 1962). In $G$. telchitta the abductor muscles are less developed as compared to $H$. fossilis and $C$. batrachus. The abductor muscle is present only on the oral side of the first three gill arches. The muscle lies in all the four gill arches. Lightoller (1939) in Elasmobranch used the term pars branchialis and pars inscriptionalis. This has given rise to the abductor and adductor muscle units of teleostean fishes (Munshi and Hughes (1992).
Reiss (1881) and Rauther (1925) have suggested that the abductor muscles perform the function of propulsion of blood and renewal of respiratory water. These functions were discarded by Bijtel (1949) on the basis of the fact that abductor muscles do not show rhythmic movement. According to Munshi (1961, 1962), the abductor muscles held in the movement of gill filaments while the adductor muscles help in bringing the filament tips of a holobranch close together during coughing movement

(b) The Levatores arcuum branchialium (Levator arcus branchialis): Altogether there are twelve levatores arcuum branchialium attached to the branchial basket of $N$. hexagonolepis. Out of them, six are external while two are internal (Fig. 1 a, b, c, d). The external levatores originate from the sphenotic region of the skull (Fig. $1 \mathrm{f}$ ) and inserted on the epibranchials of the first second and third arches and the pharyngobranchial of the fourth. Two of the levatores of the fourth gill arch are attached to the small disc like piece which bears small teeth, referred as pharyngeal tooth pad

The number of internal and external units of levatores arcuum branchialium shows variation in different fish species. In $C$. batrachus and $H$. fossilis the levatores are represented by 2 internal and 2 external units (Munshi, 1961, 1962). In the hill stream fish Garra mullya, they are represented by 2 internal and 4 external levatores in three cyprinid fish viz. Chela bacaila, Labeo rohita and Cirrhinus mrigala. In Nandus nandus and Glossogobius giuris two intetnal and five external levatores are represented on each side of the branchial arches whereas (Singh,1967). Levatores arcuum branchialium of Perophthalmus vulgaris possesses one extetnal and one internal unit only on the fourth pair of branchial arches. However, in $N$. hexagonolepis there are altogether twelve levatores which perhaps provide better support to the gill arches.

(c) The Epiarcualia oblique (Epiarcualis obliquus): In $N$. hexagonolepis, the epiarcualia oblique muscles originate from the epibranchials and extend on to the pharyngobranchial of the respective gill arches. This muscle is represented on the second and fourth gill arches only (Fig. 1 d). The former is more developed than the latter. Contraction of this muscle is followed by the sliding of the epibranchial over the pharyngobranchial.

The epiarcualia obliqui arises only from the fourth epibranchial in $H$. fossilis and Notopterus notopterus and slide the epibranchial over the 


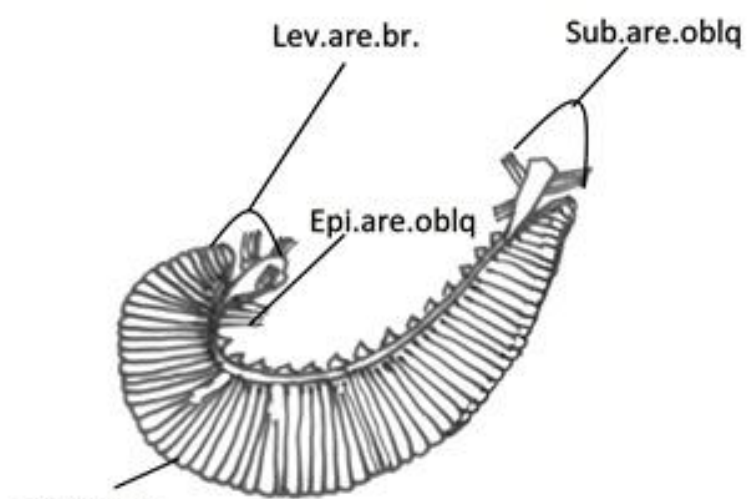

Prm.gl.Iml.

(a)

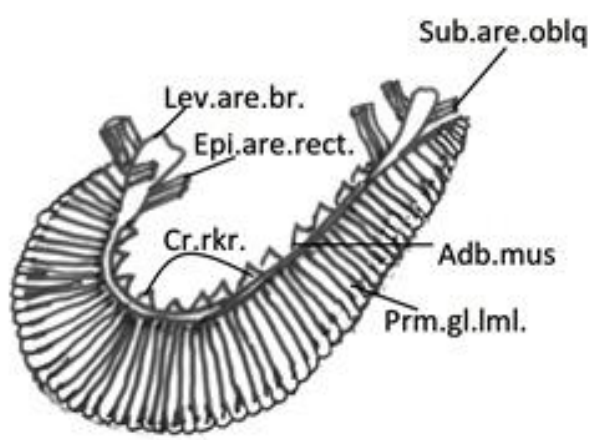

(b)

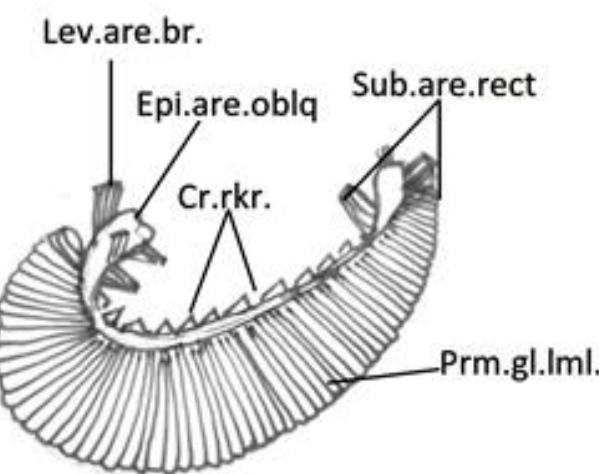

(c)

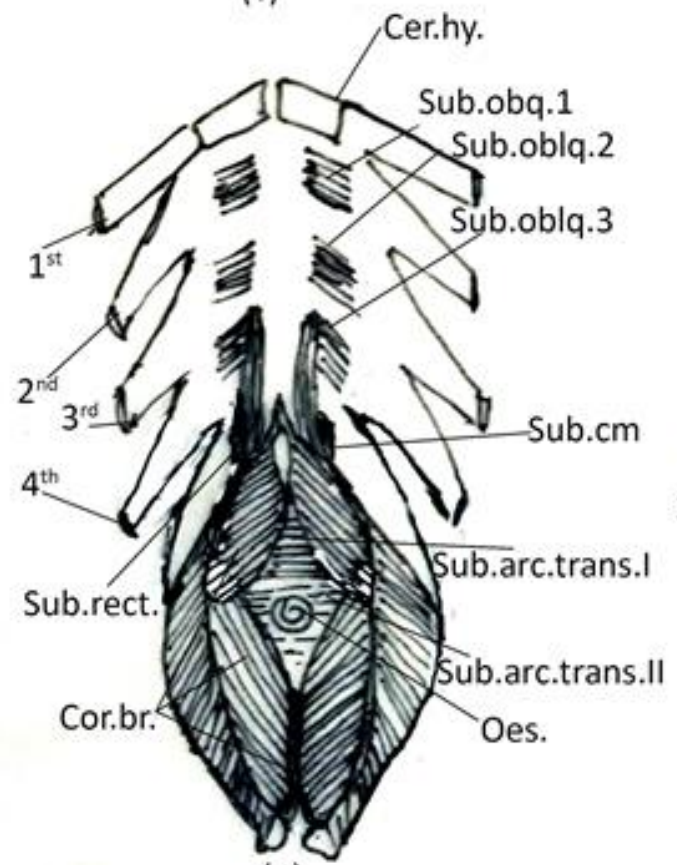

(e)

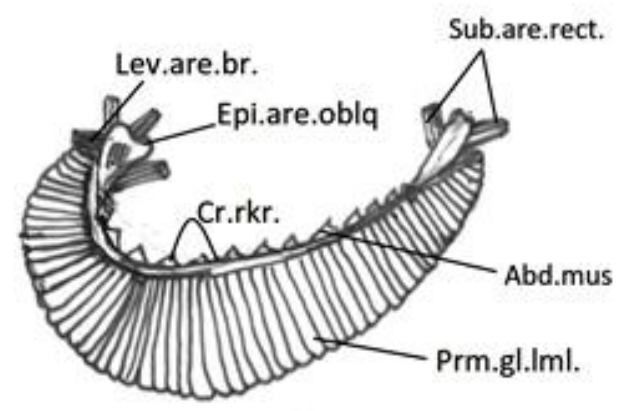

(d)

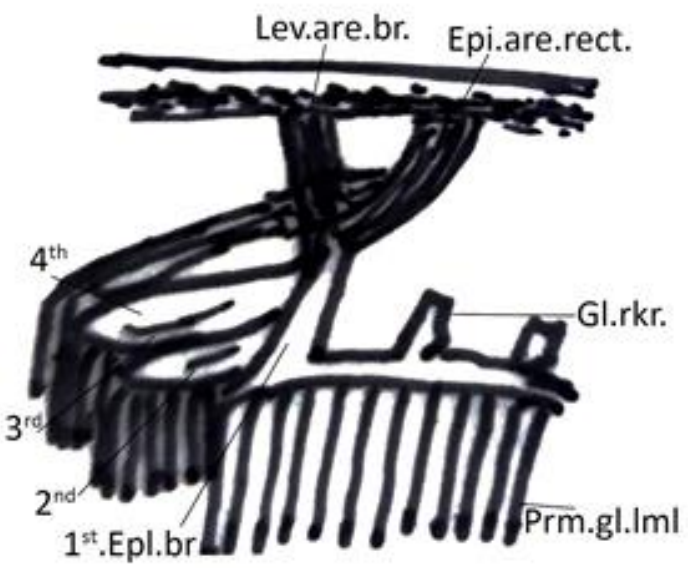

(f)

Figure 1. Branchial muscles: (a), (b), (c), and (d) Diagrammatic representation of the first, second, third and fourth gill arches showing different branchial muscles (X2 nat. size). (e) The ventral branchial muscles, their origin and insertion on the branchial arches as seen from below (X 2 nat. size). (f) Lateral view of the deeper part of the branchial cavity after the removal of the first gill arch to show the branchial muscles associated with the second, third and fourth gill arches X.2 nat. size. Abbreviations: Abd Mus= abductor muscles, Add Mus= Adductor muscles, Cera. hy.= Ceratohyal, Cera.br. = Ceratobrachial, Cor. br.= Coracobranchial, Epi. arc. obliq.= Epiarualia oblique, Epi. arc. rect. $=$ Epiarcualia recti, Epi.br. = Epibranchial, Gl= Gill, Gl.rkr= Gill raker, Lev. arc. br.= Levatores arcuum brachialium, Oes= Oesophagus, Pr $. \mathrm{gll} . \mathrm{ml} .=$ Primary gill lamellae, Sub arc oblq= Subarcualia obliqui, Sub. arc. rect.= Subarculia recti, Sub. arc.tran.= Subarculia transverse,nat. $=$ natural. 
Table 1. Branchial muscles of $N$. hexagonolepis (McCleland)

\begin{tabular}{|c|c|c|c|c|c|}
\hline Muscles & $1^{\text {st }}$ gill arch & $2^{\text {nd }}$ gill arch & $3^{\text {rd }}$ gill arch & $4^{\text {th }}$ gill arch & Function \\
\hline \multicolumn{6}{|l|}{$\begin{array}{l}\text { a) Constrictores branchiales (constrictor } \\
\text { branchialis) }\end{array}$} \\
\hline $\begin{array}{l}\text { i) Abductor muscles between the heads of } \\
\text { gill rays and gill arch. }\end{array}$ & present & present & Present & Present & $\begin{array}{l}\text { For the movement of the gill } \\
\text { filaments and for opening } \\
\text { the gill slits during coughing } \\
\text { movements. }\end{array}$ \\
\hline ii) Adductor muscle between the gill rays. & Present & Present & Present & Present & $\begin{array}{l}\text { For the suspension of the } \\
\text { gill arches and the widening } \\
\text { and narrowing of the } \\
\text { pharynx. }\end{array}$ \\
\hline $\begin{array}{l}\text { b) Leavator archuum branchialium } \\
\text { (Leacator arcus branchialis) }\end{array}$ & $\begin{array}{c}\text { Present } \\
2 \text { external } \\
1 \text { internal }\end{array}$ & $\begin{array}{c}\text { Present } \\
1 \text { external } \\
2 \text { internal }\end{array}$ & \begin{tabular}{|c|} 
Present \\
2 external \\
1 external \\
\end{tabular} & $\begin{array}{c}\text { Present } \\
2 \text { external } \\
1 \text { internal } \\
\end{array}$ & \\
\hline $\begin{array}{l}\text { c) Epiarcualia obliqui (Epiarcualis } \\
\text { obliquus) present between epi and } \\
\text { pharyngobranchial of the same arch. }\end{array}$ & Absent & Absent & Present & Present & $\begin{array}{l}\text { Bring epi- and } \\
\text { ceratobrachial arches } \\
\text { together }\end{array}$ \\
\hline $\begin{array}{l}\text { d) Epiarcualia recti (Epiarcualis rectus) in } \\
\text { the dorsal interarcual muscle. }\end{array}$ & Absent & Absent & Absent & Absent & $\begin{array}{l}\text { Approximately the dorsal } \\
\text { parts of the arches. }\end{array}$ \\
\hline $\begin{array}{l}\text { e) Epiarcualia transversi } \\
\text { (Epiarcalistransversus) }\end{array}$ & Absent & Absent & Absent & Absent & $\begin{array}{l}\text { Constriction of the floor of } \\
\text { the pharynx. }\end{array}$ \\
\hline f) Attractores arcuum branchialium & Absent & Absent & Absent & Absent & $\begin{array}{l}\text { Approximation of the epi- } \\
\text { and ceratobranchial joints }\end{array}$ \\
\hline $\begin{array}{l}\text { g) Subarcualia obliqui (Subarcualis } \\
\text { obliquus) present between cerato and } \\
\text { hypo-branchial of the same arch. }\end{array}$ & Present & Present & Absent & Absent & $\begin{array}{l}\text { Forward and backward } \\
\text { movements of lower ends of } \\
\text { the branchial arches }\end{array}$ \\
\hline h) Subarcualia recti (Subarcualis rectus) & Absent & Absent & \begin{tabular}{|c|} 
Present \\
covers $3^{\text {rd }}$ \\
gill arch \\
\end{tabular} & $\begin{array}{c}\text { Present } \\
\text { covers } 4^{\text {th }} \\
\text { gill arch } \\
\end{array}$ & $\begin{array}{l}\text { Forward and backward } \\
\text { movements of the lower } \\
\text { ends of the branchial arches. }\end{array}$ \\
\hline $\begin{array}{l}\text { i) Subarcualia transversi I and II } \\
\text { (Subarcualia transversus) } \\
\text { coracobranchiales. There are three } \\
\text { Coracobranchials. }\end{array}$ & Absent & $\begin{array}{c}\text { Absent } \\
,\end{array}$ & Present & Present & $\begin{array}{l}\text { Constriction of the floor of } \\
\text { the pharynx } \\
\text { Connect the pectoral girdle } \\
\text { with the central parts of the } \\
\text { posterior branchial bars }\end{array}$ \\
\hline
\end{tabular}

pharyngobranchial by contraction. This muscle is feebly developed both in $H$. fossilis and $N$. notopterus.

However, in $C$. batrachus there is one well developed and another ill-developed epicarcualia obliqui muscle represented in the third and fourth epibranchials respectively in connection with the second pharyngobracnials. The epiarcualia obliqui muscles, in case of $N$. hexagonolepis show feebly developed shows similarity with that of cyprinid fishes viz. $C$. bacalla, C. mrigala and L. rohita where this muscle is feebly developed and are almost functionless

(d) The Epiarcualia recti (Epiarcualis rectus): Two epiarcualia recti originating from the epibranchials of the second and fourth branchial arches, one from each arch connects the other gill arches laterally with one another at the level of epibranchials (Fig. 1b).

The epiarcualia recti muscle connects the fourth gill arch with os-phrangeum in $P$. vulgaris for the movement of the teeth bearing organ. It arises from the tip of the short posterior limbs of the Y shaped third epibranchial in N. notopterus like in the case of $H$. fossilis, but in case of $N$. hexagonolepis only one epirculia recti muscle develops obliquely from the second epibranchial and connects with the third gill arch like in Cyprinus carpio, C. batrachus and G. telchitta. It is responsible for approximation of the third and fourth gill arches (Munshi, 1962). It acts as approximator of the dorsal parts of the arches similar to the epiarculia recti of $C$. batrachus

(e) The Attractores arcuum branchialium (Attractor arcus branchialis): This is either ill developed or absent not clearly visible in $N$. hexagonopepis.

The presence of attractores arcuum branchialium at the angle of epiceratobranchial joint as in the case of $G$. telchitta and other siluroids viz. C. batrachusand $H$. fossilis (Munshi, 1961,1962) and N. notopterus (Shrestha and Subba, 2006) is not clear or least developed in the case of cyprinids viz. $C$. bacaila, C. mrigala, L. rothita and $N$. hexagonolepis. 
(f) The Subarcualia oblique (Subarcualis obliquus): In $N$. hexagonolepis this muscle is represented in the first branchial arch by 3, likewise in the second by 3. (Fig. 1 a, b). It develops in association with respective branchial arches. It acts as approximator of the cerato and hypobranchial element. Two pairs of subarcualia obliqui muscles have developed in relation to the first two branchial arches of $N$. notopterus and $C$. carpio. The similar situation was observed in case of $N$. hexagonolepis. In this respect, it is similar to C. batrachus (Munshi 1961) and $H$. fossilis (Munshi, 1962), Amphipnous cuchia (Munshi and Singh, 1968) and G. telchitta (Subba and Ghosh,1999). The subarcualia oblique muscles present in siluroids such as $C$. batrachus, $H$. fossilis and G. telchita are unforked, whereas it is normally forked in case of certain cyprinid viz. L. rohita in its disposition, number and function. Forked subarculiaobliqui were observed in $N$. hexagonolepis. These muscles originate from the fourth ceratobranchials and run upwards to become inserted on the third hypobranchials in case of siluroidsbut in the case of cyprinoid fishes viz, $L$. rohita and $C$. mrigala in which the ceratohyals are connected with ceratobranchials by the recti muscles. The latter situation was recorded in case of $N$. hexagonolepis.

(g) The Subarcualia recti (Subarcualis rectus): The subarcualia recti muscles arise from the second, third and fourth gill arches. The subarcualia recti of the second gill arch runs forward over the first gill arch to become inserted on the ceratohyal of the hyoid arch. It develops from its hypobranchial (Fig. 1e). The subarcualia recti of the third gill arch originate from its hypobranchial and become inserted on the ceratohyal of the second gill arch. Similarly, the next subarcualia recti take its origin from the fourth gill arch and inserts on the third ceratohyal. Thus, the three recti muscles do connect the ventral ends of our arches with each other. The forward and backward movements of the lower ends of the branchial arches to show their activities with the help of these muscles.These muscles show similarity with other cyprinids viz.L.rohita and c.mrigala but differ with siluroids fishes in their disposition and functions

(h) The Subarcualia transverse (subarcualis transversus): In $N$. hexagonolepis, two subarculia transversi namely subarcualia transversi i. and subarcualia transversi ii. were observed. The subarcualia transversi i. are stouter than the second and lie anterior to the second which remain just above the oesophagus. The former seemed to bridge the third and fourth ceratobranchials of one side with the partners of the other side. The muscle fibres of the subarcualiatransversi ii originate from the side edge of each inferior pharyngeal bones and hold them together. It lies below the fourth branchial arch. (Fig. 1 e) The subarcualia obliqui, subarculia recti and subarcualia transversi are together known as the muscles of subarcuales ventrales.

The subarcualia transversi are sheets of muscles situated transversely. In disposition, the two sheets of subarcualia transverse muscle of G. telchitta resemble to those of $C$. bacalia (Singh 1967) and H. fossilis (Munshi, 1962) but it differs from C. batrachus (Munshi, 1961) where the two sheets are very closely situated. In G. mullya, another hill stream fish the muscle is represented by only one sheet situated much beyond the position of branchial arches to hold the interior pharyngeal bones together (Saxena, 1960).

(i) The Coracobranchiales (Coracobranchialis): Three pairs of coracobranchiales were observed in $N$. hexagonolepis. The first and second pairs are ovate. The first pair is located ventral to the oesophagus. Their broader parts touch each other but their tapered portions remain being departed each other forming Vshaped structure and the tapered parts get inserted beneath the boarder parts of the second pair which are also more or less similar to the first pair but they are shorter than the former and form inverted V (Fig. 1e). The third pair is spindle shaped and remain covering the first and second from their sides (Fig. 1e). The muscles of all the coracobranchiales originate from the different regions of cleithrum of the pectoral girdle and remain between the fourth pairs of branchialis (Fig. 1e).

In $N$. hexagonopepis, the inferior pharyngeal bone is connected with ventral parts of the posterior branchial bars by two sheets of obliquely situated muscles, collectively called coracobranchiales as observed in a cyprinoid fish, C. bacaila (Singh, 1967). The coracobranchiales on the basis of their position is named external and internal. The subdivision of the coracobranchiales is regarded as a primitive condition of the muscle in teleosts (Nelson,1967). Interestingly the coracobranchiales have not been observed in C. batrachus and H. fossilis (Munshi, 1961, 1962). 
On the basis of the present observations it may be concluded that the branchial muscles of $N$. hexagonolepis closely resemble cyprinid fishes. The branchial muscles in $N$. hexagonolepis, G. mullya (Saxena, 1960), C. capio, C. bacaila (Singh, 1967) show much similarity in their general plan and both have well developed coracobranchales. But the numbers of coracobranchiales observed in $\mathrm{N}$. hexagonolepis were two pairs.

Presence of coracobranchiales seems to be a cyprinid character as has been observed in $G$. mullya (Saxena, 1960) and C. bacaila (Singh, 1967), and are absent in most siluroid fishes.

\section{Acknowledgements}

The authors thankfully acknowledge the sincere help extended by Mr. Gyan Bahadur Shrestha, Mrs. Keshika Shrestha, Kalpana Shrestha and their family members of Dumrebesi, Dhankuta in fish collection.

\section{References}

Bijtel, J.H. 1947. The mechanism of movement of the gill filament in Telostei. Experimentia, Basel. 3: 158-160.

Bijtel, J.H. 1949. The structure and the mechanism of the movement of the gill filaments in teleostei. Arch. Neeri. Zool. Bd. 8: 267-288.

Duvernoy, M. 1839. Du mechanism de la respiration dons less poisons. Ann des sciences naturelles, see sere Tome 13.

Edgeworh, F.H. 1935. The cranial muscles of vertebrates. Cambridge University press, Cambridge.

Kesteven, H.L. 1942-43. The evolution of the skull and cephalic muscles, a comparative study of their development and adult morphology part I. The fishes. Mem. Austr. Museum, Sydney 8: 1-63, 63132.

Lightoller, G.H.S. 1939. A study of the comparative anatomy of the mandibular and hyoid arches and their musculature. Trans. Zool. Soc., Lond. 24: 394-444.

Munshi, J.S.D. 1961. The accessory respiratory organs of Clarias batrachus (Linn.). J. Morph. 109: 115-140.

Munshi, J.S.D. 1962. On the assessor respiratory oragans of Heteropneuste sfossilis. Proc. Roy. Soc. Edin 68: 128-146.

Munshi, J.S.D. and G.M. Hughes 1992. Air breathing fishes of Inida: Their structure, function and life history. Oxford and IBH Publishing Co. Pvt. Ltd. New Delhi. 338p.

Munshi, J.S.D. and B.N. Singh 1968. On the respiratory organs of Amphipnous cuchia (Ham. Buch). J. Morph. 124: 423-444.

Nelson,G.J.1967. Branchial Muscles in some generalized Teleostean fishes.Acta. Zoologica.Bd, 277-288.

Rauther, M. 1925. Die syngnathiden des Golfa di Nepoli, Publicatondellastatione di Naapoli, 364 Monographia.

Reiss. J.A. 1881. De bauder Kiemenblaffer beiden knochen fishean. Arch. Natur-gesch. 47: 518-550.

Saxena, S.C. 1960. The cranial musculature of a hill stream cyprinoid fish, Garra mullya (Skyes). Proc. Nat. Inst. Sci., India 26(4): 176-188.

Shrestha, P. and B.R. Subba 2006. Branchial muscles of Notopterus notupterus (Pallas) and Cyprinus carpio communis (Linnaeus). In Natural Resource Management (Karmacharya, S.B., M.R. Dhakal, S.N. Jha, T.N. Mandal, M.K. Chhetri, B.R. Subba, U. Koirala, B. Niroula and K.P. Limbu Eds.). Nepal Biological Society, Biratnagar and Ecological Society, Kathmandu, Nepal. pp. 316327

Singh, B.R. 1967. Branchial muscles and their mode of working in some Cyprinoids. Ind. J. Zool. 8(1): $1-12$.

Subba, B.R. and T.K. Ghosh 1999. Branchial muscles of a hill-stream Silluroid fish, Glyptothorax telchitta (Ham.). J. Freshwater Biol. 11(1-2): 5359. 